\title{
English as a Global Language and the Effects on Culture and Identity
}

\author{
Ibrahim Alfarhan \\ Graduate Student, School of Education Saint Louis University, St. Louis, United States \\ Ibrahim_uni@hotmail.com
}

Abstract: The purpose of this paper is to discuss the concepts of English globalization and also its effects on cultural identity. This paper examines how second English language learners use English at the expense of their traditional languages. It also examines how second language acquisition influences one's cultural identity. Research evidence from various articles used in this paper confirms that the globalization of English is detrimental to the cultural identity of the given group. Language is considered as one of the most effective ways of determining a person's identity and cultural background. This means that without language, it can be difficult to establish one's cultural identity. Again, many people use English frequently when they communicate; however, as Ged (2013) explains, second language acquisition may lead to the loss of some aspects or knowledge about the first language. The effects of second language acquisition can be both negative and positive. Johnson (2009) explains that globalization of English language and its effects on cultural identity needs to be understood in three main aspects which will be discussed in this paper; for example, English as an instrument for economic success, English as a tool for cross-cultural communication, and also English as a passing phase or lingua franca of the past. Through the analysis of these three major dimensions, we will be able to establish the effects of English globalization on cultural identity.

Keywords: Global language, Identity, Cultural identity, globalization, Cross-Cultural Communication.

\section{INTRODUCTION}

English has become a global language with over 380 million people speaking it as their first language and over 200 million people taking it as their second language. Another billion of people are in the process to learn it. English has been majorly associated with the western nations such as US, Canada, or the UK. However, with the world's globalization majorly in the economic sector, English has been seen to play a great role in facilitating communication between people of different linguistic backgrounds. Again, globalization in the education sector where people move to other countries to study has also influenced the development of English. English has become the world's language of communication as it is used in various sectors; for example, commerce, technology, politics, and diplomacy. English is everywhere; we can see it everywhere we move.

However, the effects of this globalization have affected the society in various ways; loss of cultural identity is one of the major effects that are associated with the globalization of English. This paper is going to examine the globalization of English and how it affects the language acquisition and cultural identity of the people taking it as a second language like the third world countries in Africa and Asia.

\section{GLOBALIZATION OF ENGLISH ITS EFFECTS ON CULTURAL IDENTITY}

The globalization of English language can be understood in various aspects; for example, as an instrument for economic success or the creator of new inequality class, a tool for cross-cultural communication and awareness, and as a passing phase of lingua franca (Johnson, 2009). 


\section{ENGLISH AS AN INSTRUMENT FOR ECONOMIC SUCCESS}

First, as an instrument for the economic success of creator of new inequality class, English has been a powerful force behind the development of business institutions. As a result, a new class of inequalities was created that was majorly based on the language proficiency. Research indicates that the English language has influenced the development and advancement of the economic sector in a powerful way (Johnson, 2009). As people struggle for self-sufficiency and attain success, English remains a significant factor towards realizing these goals. English is said to promote the economic sector in various ways; for example, it provides people with the basic skills that enable them to cope with the modern age of technology (Seppala, 2011). Proficiency in the English language enables one to understand the basic skills needed in the modern life; for example, proficiency in computer and driving. With the technological advancement, English still remain the dominant language of communication for many people. Therefore, attaining proficiency in English gives someone the perfect opportunity to understand the modern society. English is depicted as a form of cultural capital.

Again, as people continue to interact due to different reasons; English remains the dominant language for communication between them (Poggensee, 2016). English enables people to communicate effectively across various lingual borders. Business organizations thrive and they seek to expand their operations internationally to other countries across the world. Most people learn English not because they want to know it for the sake but to enable them to attain a good job. People in the third world countries seek to learn English

So that they can get a better job. In order to attain the better job of their dream it needs them to go through various challenging situations; for example, going through the whole education system from the kindergarten level to the university. This may take longer than one could expect; but because they need to attain the best they have to go through the system to be certified that they are eligible to get the jobs. Although in education, the purpose of learning a language is to be able to comprehend and communicate in a new language, the whole idea is to become successful economically in the society by acquiring a better job (Kanno \& Varghese, 2010).

The main purpose of a language is to promote communication (Kanno \& Varghese, 2010); however, the globalization of English has proved this statement to be wrong. Language is no longer for communication mainly, but rather, there is a hidden agenda behind the struggling to learn and attain a new language. Research indicates that the globalization of English has led to the emergence of a new sense of identity where the people proficient in English regards themselves to belong to a certain group. Cultural identity is mainly influenced by language (Hatoss, 2003); therefore, the new class that is formed by the proficient second English language speakers in the third world countries like Africa and Asia is mainly influenced by the English language. Scholars refer to English as a kit that signals membership in a specific group.

English has influenced even other cultures that have been known to be conservatives like the Chinese. China is one of the countries where culture is still regarded as important and protected at any cost. However, internationalization has influenced their dedication to culture; and over the past years we have witnessed several changes (Johnson, 2009). At first, the Chinese government refused to accept English to be taught in the schools.

However, changes were made due to their increased contact with the outside world. Nowadays English is taught in various schools, although the main language of communication and instruction in schools remain mandarin. According to John (2009), the internationalization has greatly influenced China to learn English. Nowadays, many Chinese students learn English as foreign language for internationalization purposes. The international events such as Olympic Games that were held in Beijing in 2008 at some point forced some people to improve on their English skills. Taxi drivers, official games staff, hotel management and staffs were forced to improve their English skills even if they did not want to. 
Research indicates that language plays a significant role in determining the identity of a person (Lobaton, 2012). Second language acquisition is not easy; the students experience various challenges in the process. A case study in Canada indicates that students have different perceptions about their fellow colleagues who take English as their second language. As a second English learner, one does not have any culture to claim. Acquiring English as the second language means that one has to learn some of the cultural practices practiced by the English speakers, in this case, the western countries. This may force one to drop his/her culture in the process or even if he/she does not leave the native culture there will be confusion about the culture that he/she belongs to. This is because he/she will be halfway practicing his/her native culture and at the same time also trying to adapt the new culture brought by the new language acquired. Therefore, second English learners find it difficult to cope with the challenges that they face in the process of acquiring the new language. According to Lobaton (2012), second English language students have different social identities created by the new language they acquire. Again, they also have different ways of arguing about their cultural identity because of their different positions and identities that are mainly created by the acquisition of another language. According to Hatoss (2003), people can adopt a new culture without necessarily losing their first culture. However, as Lobaton (2012) argues, the confusion that emerges as a result of the second language acquisition may lead to loss of some cultural aspects of the first language. Lobaton (2012) conquers with Hatoss (2003) that language has a significant factor in determining one's cultural identity. The moment the language has been tampered with; consequently, it can also affect the cultural identity.

Hatoss (2003) claims that people cannot lose their cultural identity even if they adopt a new language or culture; however, this statement might not be entirely true. Hatoss gives an example of a Hungarian tribe in Australia and how they have stayed irrespective of their minority, they have managed to maintain their cultural practices and values over the years. Hatoss' can be at some point rejected because the strategies that the Hungarians have used to maintain their culture intact is not what many other people use when they adopt a new language and culture. For example, the Hungarians have established cultural organizations such as Hungarian Association of Australia that ensures that their cultural values and practices are upheld and passed to the next generations. However, when we talk about the globalization of English and how it affects the society's cultural identity we imply how it affects the perception of the second English learners. However, as Johnson (2009) explains, people try to associate themselves with the modernity; therefore, they may do anything to relate with the modernity including abandoning their native cultures. Therefore, the new culture that is formed by the second English learners is as a result of the globalization of the language. Everyone nowadays wants to familiarize with the modern technology that can mainly be related to English. Therefore, English as a second language at some point can lead to loss of cultural identity. Hatoss (2003) explains that in a situation where there is more than one cultural group involved, it becomes a great challenge to which culture is preferable for everyone. He further argues that in most cases the dominant culture will always influence the minor to adopt its culture. The same concept is what is applied in English acquisition as a second language. The dominant language used in schools is English, and students only use their traditional language when they get back home. Since they spend most of their times in school, the dominant culture which is English takes its course and subdue the traditional culture.

\section{ENGLISH AS A TOOL FOR CROSS-CULTURAL COMMUNICATION}

As a force behind cultural imperialism or tool for cross-cultural communication and awareness English has remained intact with its culture of origin. Unlike other languages that are considered carriers of their cultures, English is seen as a detrimental force to the world's cultural diversity (Johnson, 2009). According to Johnson, the success or failure of a language does not depend on its inherent qualities but rather, it depends on the power of the speakers (Johnson, 2009, p. 136). Scholars recognize English as a language of influence and power 
(Johnson, 2009). The spread and development of English language can be related to the colonization of the world; since Britain had many colonies, it is considered as the main party that participated in the spread of English in the third world countries in Africa and Asia. Apart from Britain colonizing many countries across the world; USA becoming superpower also contributed to the spread and development of English language (Johnson, 2009). According to Johnson, English is not only regarded as a mode of communication but rather, it is also considered as "repositories of culture and identity" (Johnson, 2009, P. 137). Johnson confirms that when the diversity of a language is reduced, it also affects its existence. The reason why the ancient languages like Latin are no longer in use is because their diversity use decreased significantly. According to Johnson, a decrease in language diversity may contribute to the loss of important concepts about traditional cultural values and practices. The same concept can be applied to the English as well; when one adopts a new language in the process of learning, one may lose some of the irreplaceable concepts and knowledge about the traditional cultural practices or values that can lead to the loss of the cultural identity of that particular group. English culture is based on the cultures of the English-speaking countries like Britain and USA. According to Johnson (2009), there is no way in which someone can learn a language without accepting the culture that comes with it. Therefore, as one learns the language he/she is forced to accept the cultures of it. According to Johnson's view, English threatens other cultures by molding the learners to accept and behave the way the English people do. The people learning the language as their second language are forced to behave like Americans or Britons and also adopt their culture. Johnson confirms that indeed, learning English as a second language significantly influences the cultures in its path (Johnson, 2009). Some people argue that the role English play is greater than just communication; for example, it acts as a lingua franca that people uses to eradicate the cross-cultural barriers communication. Some scholars argue that the rise of English as a global language is a positive influence on the development of cultures as it brings people together to share their ideas and cultures as well. English breaks the communication barriers between people from diverse cultural background and it creates a new community where people come together and share their cultures and ideas with broader audience (Johnson, 2009, p. 138). Despite its positive influence in the development of a more cohesive community where people leave their cultural differences, it also acts as a great threat to the development of other cultures.

The globalization of English is also reinforced by the learning institutions (Kanno \& Varghese, 2010). Children are now brought up without their first language because they are denied the chance of learning their first language in schools. This can be seen in most urban areas in the third world countries where the family only communicates using English. The superiority figure that English has been given has contributed to the loss of the cultural identity of these people. Again, students are becoming more interested in learning English for international purposes at the expense of their traditional languages (Kanno \& Varghese, 2010). Although, it has become a common language that people from diverse cultural backgrounds can use to understand one another, it still remains a threat to each culture involved.

Language is one of the ways that one's identity can be determined. As Wyatt (2009) defines it, "identity is who we are" (P. 6). Identity is what makes people common or the same. For example, when some says he/she is a Christian or American, there must be something or characteristic that makes him/her same with the Christians or American. Wyatt explains that identity can be understood in various dimensions; for example, the social identity which makes people identifies themselves with a larger group. The social identity includes the values, ideas, opinion, and knowledge shared by a larger group (Wyatt, 2009). There is the personal identity which makes a person unique as an individual and also the enacted identity which is the identity depicted through the language one speaks or communicates with (Wyatt, 2009). According to Wyatt (2009), the enacted identity and personal identity can never be seen the same time. It is because it is impossible to know the inside thoughts of a 
person; however, many people tend to worry about how other people would see or perceive them. According to Wyatt, the difference between the two identity dimension aspects can be determined by a language. The author further explains that language is connected to cultural identity. The social identity dimension is about culture which can also be expressed through a language. People always get carried away by how other people look at them; and this according to Wyatt (2009) is what brings the conflict between culture and language. The author further explains that culture can be expressed through the language; therefore, for one to become a member of a certain society he/she must first understand their culture and language. The discrimination that the second language learners face in schools also contributes to their abandonment of their traditional culture. Therefore, as Wyatt (2009) explains, if one loses the language then he/she loses the culture as well because the two are impossible to separate. One cannot separate the language from the culture; we share the culture through the language. Therefore, once a person has lost his/her language then it means that he/she has also lost the cultural identity because there will be no culture that that person identifies with. As Barber (2013) explains, without a language one does not claim to have a culture.

According to Seppala (2011) explains, the words people utter refer to their community's authority towards the world they live in. Seppala further claims that language is more than just understanding the grammar and vocabulary used, but rather, it also includes understanding the culture it comes from or where it is used. In the process of learning the language, one may get involved in the culture; thus, giving him/her a new identity.

\section{ENGLISH AS A PASSING PHASE OR THE PAST LINGUA FRANCA}

As a passing phase scholars argue that language can be understood as a lingua franca of the past or a different thing all together; however, as Johnson describes it either way it is more dangerous to other cultures. The superiority figure that English has been given proves to be harmful to other languages and cultures as well. English has dominated the world as it is the language that is mostly used in the advertisement, news and other social events. English has been given protection at the expense of other languages. As Ged (2013) explains, second English language acquirers must have to go beyond learning the language but also form an identity as an English speaker (P. 10). The author explains that in the process one might lose some of the knowledge about his/her original culture; thus, leading to cultural identity loss. The more one speaks a language the faster he/ she can gain proficiency in that language. Therefore, as Johnson explains, people speak English frequently and this gives it the dominance it has over other languages. Wyatt (2009) examines the effect of translation of a language to other languages across different cultures and he finds that the meaning of a word may be lost in the process of translation. Therefore, most people will tend to use English to communicate instead of going through the difficult translation process. Authors from the third world countries have mostly written their books in English so as to reach a larger audience. Using their local languages may limit their audiences. Although, they try to pass the information about their communities but the readers majorly focuses on the language that also influences their cultural identity. The fact that they have used English indicates that they have already identified themselves with the English culture; therefore, even what they write about no longer have significance. The stories they write about are based on their communities; and as Wyatt (2009) argues, some of the words lose their meaning in the process of translation.

Therefore, even if they write in English to obtain a larger audience the meaning intended may not come out as clear as it was intended. Poggensee (2016) defines the globalization of language as "the process that involves the spread of the languages used as international languages and also the disappearance of the languages that are not spoken regularly" (P. 6). The language that is frequently spoken like English will continue acquiring dominance over the rest that are not spoken. 


\section{CONCLUSION}

When children first join the school, they come with their native cultures; however, by the time they move out of school most of them would have forgotten about their native language and culture as well. Children spend most of their time in school and the official language used is English especially for second language learners. The fact that they are not allowed to use their native languages makes it difficult for them to understand its significance. The perception given to the native languages has been so negative such that the students look at it in awkward manner. However, as we have discussed in this paper, language has a great influence on cultural identity. The moment one loses the language he/she also loses the cultural identity as well. Although it is possible to learn the second language and still have knowledge of the first culture, but the globalization of English has proven that most people frequently use English and they willingly forget about their first languages. Language is what contains culture; a person without a language does not have an identity. Therefore, the globalization of English has greatly contributed to the loss of cultural identity of the second English language acquirers.

\section{REFERENCES}

Barber, S. (2013). The influence of culture and identity on second language acquisition: a perspective from Egypt. Retrieved from http://dar.aucegypt.edu/bitstream/handle/10526/3342/Shirley.thesis\%20proposal\%20 FINAL\%20.pdf?sequence=3

Ged, G. (2013). Conscious Reconstruction: The Effects of Second Language Acquisition on Self-Perception of Gender Identity.

Hatoss, A. (2003). Identity formation, cross-cultural attitudes and language maintenance in the Hungarian Diaspora of Queensland. Cultural Citizenship: Challenges of Globalization. Decan University, Melbourne, 71-77. Retrieved from https://eprints.usq.edu.au/1158/1/Hatoss_Deakin_paper.pdf

Johnson, A. (2009). The rise of English: The language of globalization in China and the European Union. Macalester International, 22(1), 12. Retrieved from http://digitalcommons.macalester.edu/cgi/viewcontent. cgi?article=1447\&context=macint Kanno, Y., \& Varghese, M. M. (2010). Immigrant and refugee ESL students' challenges to accessing four-year college education: From language policy to educational policy.

Journal of Language, Identity, and Education, 9(5), 310-328.

Lobatón, J. C. G. (2012). Language learners' identities in EFL settings: resistance and power through discourse* Las identidades de estudiantes de inglés como lengua extranjera: resistencia y poder discursivo. Retrieved from http://www.scielo.org.co/scielo.php?script=sci_arttext\&pid=S0123-46412012000100005

Poggensee, A. (2016). The effects of globalization on English language learning: Perspectives from Senegal and the United States. Retrieved fromd http://scholarworks.wmich.edu/cgi/viewcontent.cgi?article=3725\& context=honors_theses Seidlhofer, B. (2013). Oxford Applied Linguistics: Understanding English as a Lingua Franca. Oxford University Press.

Seppälä, M. (2011). The effects of the English language on the cultural identity of Chinese university students.

Wyatt, A. (2009). Identity, Language and Culture in Eva Hoffman's Lost in Translation. Retrieved from

https://www.diva-portal.org/smash/get/diva2:228969/FULLTEXT01.pdf

Citation: Ibrahim Alfarhan, Graduate Student, School of Education Saint Louis University, St. Louis, United States English as a global language and the effects on culture and identity ARJEL Volume 2016; pp:1-6

Copyright (c) 2016 Ibrahim Alfarhan, This is an open access article distributed under the Creative Commons Attribution License, which permits unrestricted use, distribution, and reproduction in any medium, provided the original work is properly cited. 